\title{
F0XP3 expression in papillary thyroid carcinoma with and without Hashimoto's thyroiditis
}

\author{
Expressão do FOXP3 no carcinoma papilífero \\ da tireoide com e sem tireoidite de Hashimoto
}

Murilo Pedreira Neves Junior'; Edgar Marcelino de Carvalho Filho²; Marcos Pedro Guedes Camandaroba3; Milena Brachmans Mascarenhas ${ }^{4}$; Thaizza Cavalcante Correia ${ }^{4}$; Yuri Costa Sarno Neves 5

\begin{abstract}
Introduction: The forkhead box P3 (FOXP3) plays a role in cell development and control. In the presence of abnormal FOXP3 expression, tumor cells may evade the immunosurveillance of lymphoid cells, the first step for the maintenance of cancer cells in the thyroid tissue. Objective: To identify the presence of FOXP3 in papillary thyroid carcinoma (PTC) with and without Hashimoto's Thyroiditis (HT). Methods: We conducted a series study of cases collected from 2000 to 2008, when 1,438 thyroidectomies were performed. We selected those diagnosed with PTC, comprising 466 cases. 30 patients were randomly selected for purposes of immunohistochemistry with antibodies against F0XP3. Result: FOXP3 revealed high positivity for PTC and positive immunostaining was present in 21 (72.4\%) from all analyzed cases. There was no difference regarding coexistent HT or not. Discussion and conclusion: In the present study, it was evidenced that the focal or diffuse FOXP3 expression was commonly observed in neoplastic cells from PTC, hence indicating that the assessment of this molecule expression in suspected cases of thyroid cancer may contribute to its diagnosis.
\end{abstract}

Key words: thyroiditis; papillary thyroid carcinoma; FOXP3; immunohistochemistry; pathology; Hashimoto's thyroiditis.

\section{INTRODUCTION}

Hashimoto's thyroiditis (HT) is the most prevalent autoimmune thyroid disease, in which cell infiltration is perceived, mainly lymphocytes, followed by gradual destruction of the parenchymal tissue of the thyroid and replacement by fibrosis ${ }^{(20)}$. HT has a prevalence rate of $1 \%$ to $4 \%$ and an incidence of 30 60/100,000 annually, being more common in women ${ }^{(7)}$.

Thyroid tumors are frequent endocrinopathies in the population between 20 and 60 years of age. Approximately 40\% of individuals have thyroid nodules, of which approximately $5 \%$ to $10 \%$ are malignant. The most frequent tumor is the papillary thyroid carcinoma (PTC) $)^{(18)}$.

The association between PTC and HT is widely described insofar as both share several morphological, immunohistochemical and molecular features ${ }^{(2)}$. Patients with PTC are four times more likely to have coexistent HT in comparison with patients with other thyroid diseases, which suggests an association between chronic inflammation and cancer development in the thyroid gland ${ }^{(1,17)}$. It is claimed that the presence of chronic inflammatory process observed in HT may be the triggering factor in carcinogenesis through the activation of genes or receptors involved in cell cycle ${ }^{(3,4)}$.

First submission on 18/02/13; last submission on 24/06/13; accepted for publication on 25/06/13; published on 20/08/13

1. Doctor in Medicine by Universidade Federal da Bahia (UFBA); assistant professor at UFBA- Medical School.

2. Doctor in Medicine by UFBA; professor at UFBA-MS; chief at the Immunology Department - Professor Edgard Santos University Hospital-UFBA

3. Resident of Oncology at Hospital AC Camargo, São Paulo.

4. Graduate student in Medicine at Escola Baiana de Medicina e Saúde Pública.

5. Graduate student in Medicine at UFBA-MS. 
Forkhead box P3 (FOXP3) belongs to the family of forkhead box (FOX) transcription factors, characterized by a forkhead domain (FKH) that binds to deoxyribonucleic acid (DNA) ${ }^{(13)}$. Located on regulatory $\mathrm{T}$ lymphocytes (Treg), FOXP3 plays a role in cell development and control ${ }^{(8)}$. Regulatory $\mathrm{T}$ cells play a pivotal role in protecting body cells from autoimmune reaction, inflammation and tissue destruction by blocking $\mathrm{T}$ cells. Additionally, FOXP3 is crucial in this regulation ${ }^{(9,21)}$. Low FOXP3 expression on Treg cells (CD25 and CD4) predisposes to numerous autoimmune diseases ${ }^{(13)}$. In the presence of alterations in FOXP3 expression, surveys have shown that this could affect tumor cell evasion of lymphoid cell immunosurveillance ${ }^{(8,11)}$. Inflammation favors the expansion of Treg cells in the tissue, the first step in the maintenance of cancer cells ${ }^{(12)}$. A high density of Treg cells has been demonstrated in the peripheral blood of cancer patients, which corroborates this hypothesis ${ }^{(14)}$.

In this context, a better understanding of the role of FOXP3 in cancer may allow its use as a biomarker and prognostic factor, targeting the treatment of malignant neoplasias ${ }^{(12,14)}$. The association of FOXP3 expression and tumor cell proliferation in isolated PTC or with coexistent HT is unknown ${ }^{(22)}$. This fact allows us to enquire if the identification by means of FOXP3 immunohistochemistry could suggest a carcinogenic role in the development of PTC and if there is a difference in its expression in the absence and presence of HT.

Thus, this study aims to identify FOXP3 expression in PCT with and without HT.

\section{METHODS}

We conducted a series study of cases from 2000 to 2008, in which a total of 1,438 thyroidectomies were performed at the Surgery Department from Hospital São Rafael, Salvador-Bahia, Brazil. A total of 466 cases of PTC were selected. A review of the slides was conducted in order to identify cases of HT. The data were stored in a database for statistical analysis. Afterwards, 30 cases of PTC were randomly selected for purposes of immunohistochemistry with antibody against FOXP3. Randomization was generated through Random Allocation Software.

Two groups were considered: PTC cases without HT and PTC cases with HT.

Immunohistochemistry was performed by cutting the blocks and preparing $5 \mu \mathrm{m}$ slides, which had been previously silanized. The antigen retrieval was conducted with ethylenediaminetetraacetic acid (EDTA) PH9 and immunostaining was carried out with anti-
FOXP3 [mAbcam 22510] Abcam ${ }^{\circledR}$ clone 236A/E7 Cambridge, UK. The revelation was conducted with streptavidin in phosphate buffered saline solution (PBS) and chromogenic diaminobenzidine substrate (DAB) for thirty minutes, followed by washing with distilled water and counterstaining with Harris hematoxylin.

Slides were considered positive for FOXP3 when there was evident staining in PTC cells in four $400 \times$ fields. Subsequently, each case was classified as diffuse positive if more than $50 \%$ of PTC cells were stained or focal positive if less than $50 \%$ of the cells were stained. Slides were regarded as negative when there was no staining for FOXP3 in PTC. All slides were analyzed by two pathologists and conflicting results were reviewed and classified by mutual agreement.

For statistical inference, chi-square test was applied to compare data from the qualitative variables (gender, histological variant, FOXP3 expression and FOXP3 expression type). The differences were considered statistically significant when $p$-values were lower than 0.05 . The analysis was carried out using the software Statistical Package for Social Sciences, IBM (SPSS) for Windows, version 11.0. The study was approved by the Research and Ethics Committee of Hospital São Rafael on March 8, 2007.

\section{RESULTS}

30 out of 466 cases of PTC diagnosed from 2000 to 2008 were randomly selected for immunohistochemistry with the aim to determine FOXP3 expression. One case was excluded from this sample owing to the fact that the paraffin block presented artifacts (Figure 1). The demographic characteristics, HT frequency and FOXP3 expression in immunohistochemistry are demonstrated in Table 1.

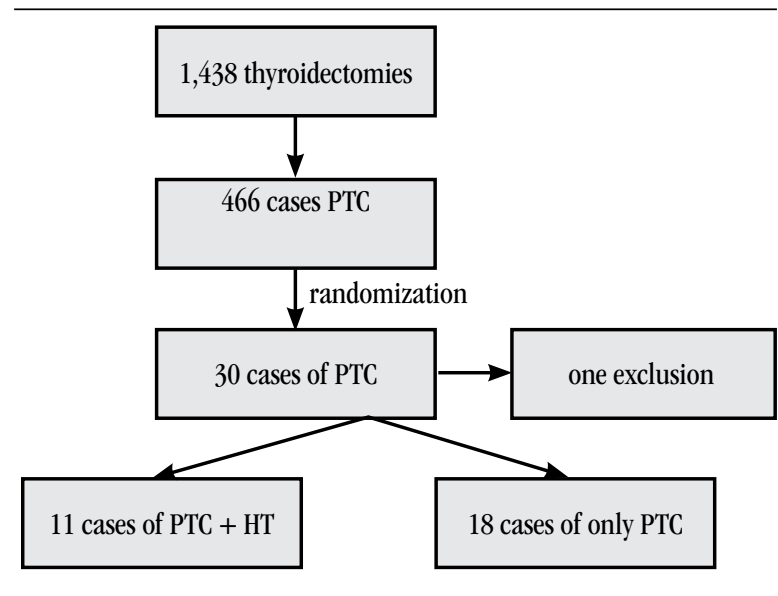

FIGURE 1 - Flow chart of the study design and case series PTC: papillary thyroid carcinoma; HT: Hashimoto's thyroiditis. 
TABLE 1 - Demographic characteristics, frequency of HT and FOXP3 expression in the subgroup of 29 cases of PTC that underwent immunohistochemical examination

\begin{tabular}{cc}
\hline Variables & $n=29$ \\
\hline Female & $23(79.3 \%)$ \\
Age in years (mean) & 42 \\
Frequency of HT & $11(37.9 \%)$ \\
FOXP3 expression & $21(72.4 \%)$ \\
\hline
\end{tabular}

HT: Hashimoto's thyroiditis; FOXP3: forkhead box P3; PTC: papillary thyroid carcinoma.

It was noticed that $23(79.3 \%)$ out of 29 cases that underwent immunohistochemical examination were female and six (20.7\%) were male. The mean age was 42 years. 18 patients (62.1\%) were diagnosed exclusively with PTC and 11 (37.9\%) had coexistent HT. The positive immunostaining for FOXP3 was present in 21 (72.4\%) from all the analyzed cases (Table 1).

$13(72.2 \%)$ out of 29 cases affected exclusively by PTC were positive for FOXP3, whereas 8 (72.7\%) with PTC and coexistent HT were positive for FOXP3 (Figure 2). This difference was not statistically significant $(\phi=0.98)$.

6 (46.2\%) out of 13 positive cases diagnosed exclusively with PTC were focal positive and 7 (53.8\%) yielded diffuse positive result. 2 out of 8 positive patients with joint diagnosis of PTC and HT showed focal positive result and 6 (75.0\%) were diffuse positive for FOXP3. This difference between the two groups was not statistically significant (Table 2).

Figure $\mathbf{3}$ shows the immunohistochemical slide preparation of PTC tissue with positive result for FOXP3. We observe clear staining for FOXP3 in PTC and negativity for such immunostaining in normal thyroid tissue, with positive internal control for the reaction evidenced in positive Treg cells from HT lymphoid infiltrate.

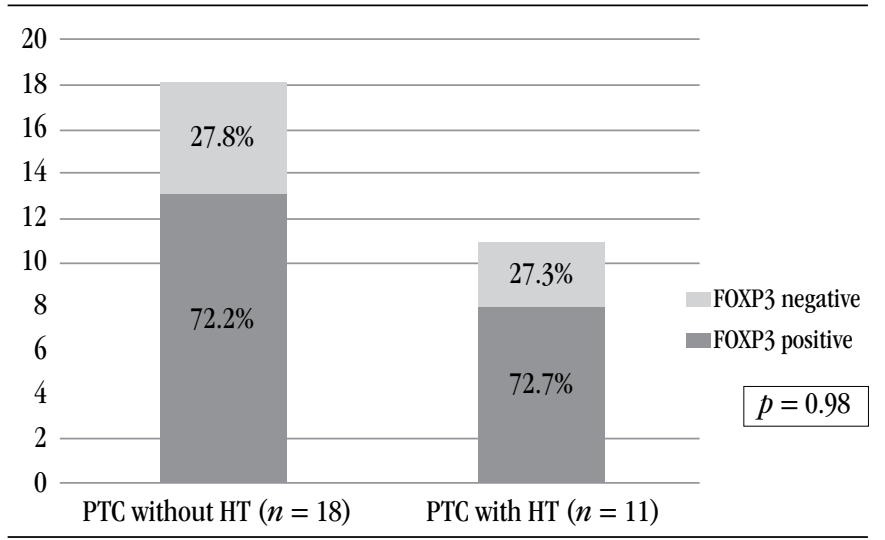

FIGURE 2 - Frequency of FOXP3 expression in 29 cases of PTC with and without HT FOXP3: forkhead box P3; PTC: papillary thyroid carcinoma; HT: Hashimoto's thyroiditis.
TABLE 2 - Analysis of gender, frequency and type of FOXP3 expression in immunohistochemical analysis of 29 cases of PTC with and without HT

\begin{tabular}{cccc}
\hline Variables & $\begin{array}{c}\text { PTC without HT } \\
(n=18)\end{array}$ & $\begin{array}{c}\text { PTC with HT } \\
(n=11)\end{array}$ & $p$ value \\
\hline Female & $13(72.2 \%)$ & $10(90.1 \%)$ & 0.228 \\
F0XP3 expression & $13(72.2 \%)$ & $8(72.7 \%)$ & 0.976 \\
Type of expression & $n=13$ & $n=8$ & 0.195 \\
Focal & $6(46.2 \%)$ & $2(25 \%)$ & - \\
Diffuse & $7(53.8 \%)$ & $6(75 \%)$ & - \\
\hline
\end{tabular}

FOXP3: forkhead box P3; PTC: papillary thyroid carcinoma; HT: Hashimoto's thyroiditis.

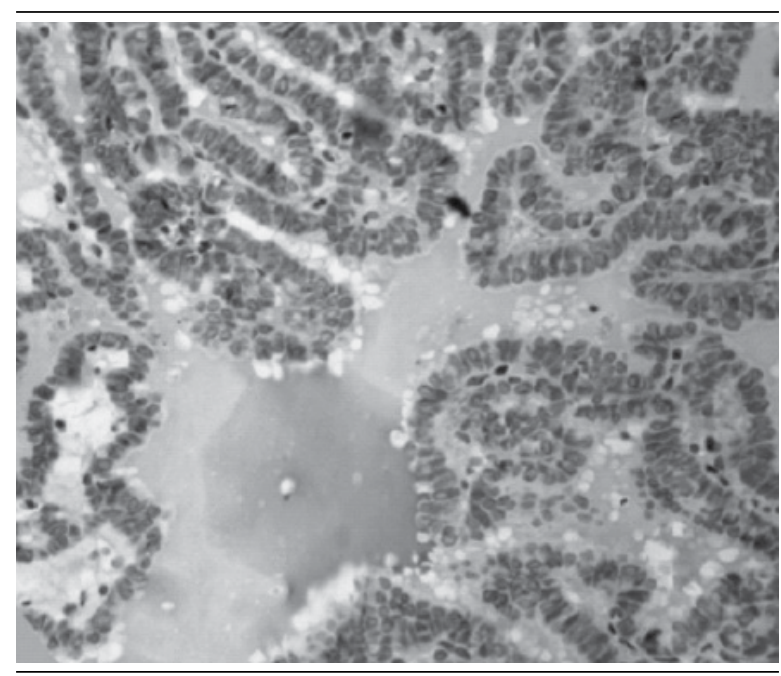

FIGURE 3 - Optical microscopy of PTC tissue showing positive staining for FOXP3 in immunobistochemistry

PTC: papillary thyroid carcinoma; FOXP3: forkhead box P3.

\section{DISCUSSION}

FOXP3 expression in PTC was evidenced herein by immunohistochemistry carried out with specific antibodies for F0XP3. We obtained high positivity for FOXP3, thus 21 out of 29 patients with PTC yielded positive result, corresponding to $72.4 \%$ of this group. Recently, FOXP3 expression has been detected in 91.9\% of PTC cases $(\phi<0.0001)^{(5,19)}$.

Autoimmune diseases such as HT are associated with failure in the mechanisms of immune response regulation. It is deemed possible that during the chronic inflammatory process, Treg lymphocytes act in the inflammatory site via its mechanism of modulation, with consequent reduction in immune response against neoplastic cells and subsequent development of cancer ${ }^{(7,9,21)}$.

The role of inflammation in carcinogenesis is currently accepted insofar as there has been evidence that the inflammatory 
microenvironment is an essential component of all tumors, including those in which a direct causal relationship with inflammation has not been established yet ${ }^{(10,13)}$. It is also known that the mutation rate is significantly higher in tissues with chronic inflammation in comparison with normal tissues ${ }^{(10)}$. The persistent release of inflammatory mediators by the neoplasia may lead to tumor progression by augmenting the proliferation of tumor cells, resistance to apoptosis, stimulation of angiogenesis and stromal remodeling. Moreover, it may inhibit the establishment of protective antitumor immunity ${ }^{(4,10,15)}$. Furthermore, chronic inflammation is linked to oxidative stress, which may cause DNA damage and contribute to initiate genetic alterations such as oncogene expression ${ }^{(10,16)}$. Thyroid cancers display an inflammatory component that includes different types of leukocytes and is frequently observed in thyroid tumors, particularly in $\mathrm{PTC}^{(6,10,15)}$.

Our data demonstrated that FOXP3 expression is present only in PTC and not in areas exclusively with HT. These results contrast with data recently published by Cunha et al. in 2012, in which FOXP3 expression occurred less intensely in normal tissues in comparison with $\mathrm{PTC}^{(5)}$.

The results revealed no significant difference in FOXP3 expression in PTC with or without HT, indicating that FOXP3 expression in PTC is not linked to coexistent HT. This fact suggests that HT does not appear to induce FOXP3 expression and the mechanism related to the process of malignant transformation should be responsible for the aberrant FOXP3 expression observed in the plasma membrane of PTC cells.

In the present study, we established that focal or diffuse FOXP3 expression was intensely observed in PTC neoplastic cells, indicating that the assessment of this molecule expression in suspected cases of thyroid neoplasia may contribute to the diagnosis of PTC, especially in cases of difficult diagnosis (as in cases of moderate atypia, denominated "solid cell nests" [SCN]), enabling the distinction between the latter and $\mathrm{PTC}^{(16)}$. Thus, radical procedures such as thyroidectomy may be avoided in patients with mild inconclusive nuclear atypia that has been mistaken for PTC.

\section{CONCLUSION}

This is the first study performed in order to assess the correlation of isolated PTC or coexistent HT with FOXP3 expression. The present investigation also concluded that the immunohistochemistry for this marker proved to be highly effective in cases of PTC, hence the importance of further investigations in order to reproduce and confirm these data on FOXP3 positivity, a possible marker in thyroid cancer.

\section{RESUMO}

Introdução: 0 forkhead box P3 (FOXP3) tem o seu papel no desenvolvimento e no controle celular. Na presença de alterações da sua expressão, células tumorais podem escapar da imunovigilância das células linfoides, sendo o primeiro passo para perpetuação das células cancerígenas no tecido tireoidiano. Objetivo: Identificar a presença do FOXP3 no carcinoma papilifero da tireoide (CPT), com e sem tireoidite de Hashimoto (TH). Métodos: Foi realizado um estudo de série de casos coletados no período de 2000 a 2008, quando foram realizadas 1.438 tireoidectomias. Destes, foram selecionados aqueles que apresentaram diagnóstico de CPT, perfazendo um total de 466 casos. Desse total, 30 casos de CPT foram selecionados aleatoriamente para fins de exame imuno-bistoquímico com o anticorpo contra o FOXP3. Resultado: O FOXP3 apresentou alta positividade no CPT; a marcação positiva na imuno-histoquímica esteve presente em 21 (72,4\%) de todos os casos analisados. Não bouve diferença com relação à coexistência ou não de TH. Discussão e conclusão: No presente estudo, foi documentado que a expressão difusa ou focal de FOXP3 foi intensamente observada nas células neoplásicas do CPT, indicando que a avaliação da expressão dessa molécula em casos suspeitos de neoplasia da tireoide pode contribuir para o seu diagnóstico.

Unitermos: tireoidite; carcinoma papilifero da tireoide; FOXP3; imuno-bistoquímica; patologia; tireoidite de Hashimoto.

\section{REFERENCES}

1. AHN, D. et al. Clinical relationship between Hashimoto's thyroiditis and papillary thyroid cancer. Acta Oncol, v. 50, p. 1228-34, 2011.

2. BENVENGA, S. Update on thyroid cancer. Horm Metab Res, v. 40, n. 5 , p. 323-8, 2008.
3. CIPOLLA, C. et al. Hashimoto thyroiditis coexistent with papillary thyroid carcinoma. Am Surg, v. 71, n. 10, p. 874-8, 2005.

4. COTRAN, R. S.; KUMAR, V.; ABBAS, F. Patologia: bases patológicas das doenças. 8. ed. Rio de Janeiro: Guanabara Koogan, 2010. p. 1011-47.

5. CUNHA, L. L. et al. FOXP3 expression is associated with aggressiveness 
in differentiated thyroid carcinomas. Clinics (São Paulo), v. 67, n. 5, p. 483-8, 2012.

6. ELOY, C. et al. The preeminence of growth pattern and invasiveness and the limited influence of BRAF and RAS mutations in the occurrence of papillary thyroid carcinoma lymph node metastases. Virchows Archiv, v. 459 , n. 3, p. 265-76, 2011

7. GAYATHRI, B. N.; KALYANI, R.; HARENDRA, K. M. L. Fine needle aspiration cytology of Hashimoto's thyroiditis.J Cytol, v. 28, n. 4, p. 210-3, 2011.

8. GHEBEH, H. et al. FOXP3+ Tregs and B7-H1+/PD-1+ T lymphocytes co-infiltrate the tumor tissues of high-risk breast cancer patients: Implication for immunotherapy. BMC Cancer, v. 8, p. 57, 2008.

9. HINZ, S. et al. FOXP3 expression in pancreatic carcinoma cells as a novel mechanism of immune evasion in cancer. Cancer Res, v. 67, n. 17, p. 8344-50, 2007.

10. LIOTTI, F; VISCIANO, C.; MELILLO, R. M. Inflammation in thyroid oncogenesis. Am J Cancer Res, v. 2, n. 3, p. 286-97, 2012

11. KARANIKAS, V. et al. FOXP3 expression in human cancer cells. J Transl Med, v. 6, p. 19, 2008.

12. KINIWA, Y. et al. CD8+ FOXP3+ regulatory T cells mediate immunosuppression in prostate cancer. Clin Cancer Res, v. 13, n. 23, p. 6947-58, 2007.

13. MARTIN, F. et al. Human FOXP3 and cancer. Oncogene, v. 22, p. 4121-9, 2010.
14. MICHEL, S. High density of FOXP3-positive T cells infiltrating colorectal cancers with microsatellite instability. Br J Cancer, v. 99, n. 11, 2008.

15. NEVES, J. M. P. et al. Thyroid papillary carcinoma and histologic variants linked to Hashimoto disease.J Bras Patol Med Lab, v. 45, n. 5 , p. 389-93, 2009

16. SEETHALA, R. R.; CHIOSEA, S. I. Solid cell nests, papillary thyroid microcarcinoma, and HBME1. Am J Clin Pathol, v. 134, p. 167-70, 2010.

17. STRAUSS, M.; LAURIAN, N.; ANTEBI, E. Coexistent carcinoma of the thyroid gland and Hashimotos thyroiditis. Surg Gynecol Obstet, v. 157, n. 3, p. 228-32, 1983.

18. VIERLINGER, K. et al. Identification of SERPINA1 as single marker for papillary thyroid carcinoma through microarray meta-analysis and quantification of its discriminatory power in independent validation. BMC Med Genet, v. 6, n. 4, p. 30, 2011.

19. WANG, L. et al. Somatic single-hits inactivate the X-linked tumor suppressor FOXP3 in the prostate. Cancer Cell, v. 16, n. 4, p. 336-46, 2009.

20. ZALETEL, K.; GABER, S. Hashimoto's thyroiditis: from genes to the disease current. Genomics, v. 12, p. 576-88, 2011.

21. ZHOU, X. et al. Plasticity of CD4+ FOXP3 + T cells. Curr Opin Immunol, v. 21, n. 3, p. 281-5, 2009.

22. ZUO, T. et al. FOXP3 is a novel transcriptional repressor for the breast cancer oncogene SKP2.J Clin Invest, v. 117, p. 3765-73, 2007. 